\title{
INTERLEUKIN-15: ITS ROLE IN MICROBIAL INFECTIONS
}

\section{BANNWART C.F. (1), NAKAIRA E.T. (1), SARTORI A. (1), PERAÇOLI M.T.S. (1)}

(1) Department of Microbiology and Immunology, Institute of Biosciences, São Paulo State University, UNESP, Botucatu, São Paulo State, Brazil.

\begin{abstract}
Interleukin-15 (IL-15) is a pleiotropic cytokine which regulates the proliferation, survival and the secretory activities of many distinct cell types in the body. This cytokine is produced by macrophages and many other cell types in response to infectious agents; it controls growth and differentiation of $T$ and $B$ lymphocytes, activation of Natural Killer (NK) and phagocytic cells, and contributes to the homeostasis of the immune system. The present review focuses on the biological and modulatory effects of IL-15 in microbial infections and shows that this cytokine may play a role in the host defense against infections by inducing activation of effector cells from both innate and adaptive immune system.
\end{abstract}

KEY WORDS: Interleukin-15, microbial infections, innate immunity.

CONFLICTS OF INTEREST: There is no conflict.

\section{CORRESPONDENCE TO:}

MARIA TEREZINHA SERRÃO PERAÇOLI, Departamento de Microbiologia e Imunologia, Instituto de Biociências, Campus de Botucatu, UNESP, Botucatu, SP, Brasil. Phone: 55143811 6058. Fax: $55 \quad 14 \quad 3815$ 3744. Email: peracoli@ibb.unesp.br. 


\section{INTRODUCTION}

Interleukin-15 (IL-15) was originally discovered as a T cell stimulatory agent present in the culture supernatant of a simian kidney epithelial cell line. Biologically active IL15 was characterized as being able to support proliferation of an Interleukin-2 (IL-2)dependent murine cell line (22). A special feature of IL-15 is that it shares important functional attributes with IL-2, including enhanced proliferation, survival and differentiation of many distinct cell types as NK, T and B cells $(2,9,12)$.

Whereas the extensively studied IL-2 is mainly produced by activated T cells, IL-15 mRNA is constitutively expressed by a large variety of cell types and tissues, including monocytes/macrophages, dendritic cells, and many other non-lymphoid tissues including placenta, skeletal muscle and epithelial and fibroblast cell lines (22, $39,43)$.

Three distinct high-affinity IL-15 R ( $\alpha, \alpha+\beta$ and $\alpha+\beta+\gamma)$ and one intermediate-affinity $\mathrm{IL}-15$ receptor $(\beta+\gamma)$ have been described (9). From those three chains, only $\alpha$ is private for IL-15 binding, being, however, structurally related to IL-2R $\alpha ; \beta$ and $\gamma$ chains are shared with IL-2 (21). In addition, the unique $\alpha$-chain (IL-15R $\alpha$ ) exists in eight isoforms (55). The $\gamma$-chain receptor is also shared by several other cytokines, such as IL-4, IL-7, IL-9 and IL-21, all of which use additional private receptor subunits responsible for the specificity of binding and/or downstream signaling (33). These shared receptor subunits explain the existing functional similarities between IL-2 and IL-15. Budagian et al. (8) and Mortier et al. (42) recently demonstrated that murine and human IL-15R $\alpha$ not only exist in membrane bound, but also in a soluble form. In both species, natural sIL15R $\alpha$ is constitutively generated from the transmembrane receptor through a proteolytic cleavage and this process is further enhanced by certain chemical agents such as phorbol myristate acetate (PMA). Cell-membrane expression of IL-15 might be crucial in mediating extracellular function rather than cytokine secretion and, in part, explains the difficulty to detect soluble IL-15 in biological systems (55).

IL-15-mediated signaling is better characterized in T lymphocytes and in these cells it results in the activation of Janus kinases (JAK). The $\beta$ chain recruits JAK1 whereas $\gamma$ chain activates JAK3, which in turn results in the phosphorylation and activation of transcription factors known as signal transducers and activators of transcription (STAT) 3 and STAT5, respectively (27). Phosphorylated-STAT transcription factors 
translocate to the nucleus where they bind to DNA-regulatory elements and activate gene expression (32). Additional signaling pathways activated by IL-2 and IL-15 involve the phosphorylation of the Src family tyrosine kinase. More recently, it was demonstrated that the IL-15R $\alpha$ is also capable of signaling through activation of Syk kinase (48).

Even though they present many overlapping functional properties, IL-2 and IL-15 have distinct roles in the immune system. Whereas IL-2 is mainly produced by activated $\mathrm{T}$ cells and operates as a key modulator of T-cell-dependent adaptive immune responses, IL-15 mRNA is constitutively expressed by a large variety of cell types and seems to serve to a much broader spectrum of bio-regulatory purposes. It is a cytokine of innate immunity (46) that exerts modulation of selected adaptive immune responses $(34,53)$.

Physiological functions of IL-15 reach a wide variety of cell populations. Effects on different non-immune cell types are well known and were recently reviewed by Budagian et al. (9). In the present review, we will describe only its main biological activities on cells from innate and specific immunity. IL-15 has a clear impact on neutrophil function; it enhances human neutrophil phagocytosis, stimulates IL-8 and IL-1R antagonist secretion and also inhibits neutrophil apoptosis (7, 14, 37, 48). In human eosinophils, IL-15 induces production of granulocyte-macrophage colonystimulating factor (GM-CSF) and reduces apoptosis by up-regulating the autocrine production of GM-CSF and NF-kB activation (24). Similarly to the stem cell factor and IL-3, IL-15 can also serve as a growth factor for mast cells (49). Monocyte and macrophage cell lineages answer to stimulation with IL-15 by increasing phagocytosis and microbial clearance $(17,38,54)$ and by increasing IL-8, IL-12, MCP-1 and superoxide production. IL-8 and MCP-1 further attract monocytes and neutrophils, leading to inflammatory cell accumulation. Thus, IL-15 locally produced at sites of inflammation may play a pivotal role by regulating leukocyte infiltration (4). In addition, stimulation of these cells through membrane-bound IL-15 with specific agonists (sILR $\alpha$ or anti-IL-15 antibodies) induced expression of pro-inflammatory cytokines as TNF- $\alpha$, IL-6 and IL-8, by reverse signaling (44).

IL-15 also affects development, maintenance and activation of the cells responsible for the primitive immunity such as NK and $\gamma \delta \mathrm{T}$ cells $(11,45)$. Endogenous production of IL-15 by human monocytes is required for the optimal production of IFN- $\gamma$ by NK 
cells. These cells appear to be critical in the defense against many pathogens by supplying IFN- $\gamma$, which remains the prototypic monocyte-activation factor for virtually all anti-microbial and anti-parasitic activities (26), after activation by monocytederived cytokines such as TNF- $\alpha$ and IL-12 (12). These effects over the innate immunity seem to mediate, at least partially, the increased anti-infectious activity of this cytokine that we will be referring latter in this review.

Several lines of evidence also indicated an essential role of IL-15 in modulating B cell activities. This cytokine stimulates proliferation of anti-lgM and PMA-activated B cells and the production and secretion of $\lg A, \lg G 1$ and $\lg M(2)$. In addition, IL-15 has the ability to inhibit apoptosis induced by different stimuli in human and mouse B lymphocytes (10). These effects over survival and proliferation on B cells seem to be associated with the direct production of this cytokine by follicular dendritic cells in germinal centers (47).

The importance of IL-15 for T lymphocyte development and homeostasis, and for memory CD8+ T cell and NK cell development, maintenance and activities has been well reviewed in literature $(6,34,35,53)$.

An immunological event considered fundamental to control many infectious diseases is the initial IFN- $\gamma$ production. Even though IL-12 appears to be a pivotal cytokine for IFN- $\gamma$ production by NK cell, co-stimulation with IL-15 seems to be required for its optimal production (12). Hence, IL-15 in synergy with IL-12 could induce Th1 response by $\alpha \beta T$ cells against microbial infections, especially intracellular parasites (57). Therefore, IL-15 and IL-12 produced by activated human monocytes may be important determinant for IFN- $\gamma$ production by NK cells, essential to the development of an effective innate immune response against infections, before activation of antigen-specific $\mathrm{T}$ cells (13). Thus, innate immune response serves not only to provide immediate protection against a variety of agents but also to activate adaptive immune response through cellular interactions and cytokine production.

\section{MODULATORY EFFECT OF IL-15 ON HOST RESPONSE TO MICROORGANISMS}

A few reports are available on the role of IL-15 in the host response to infection. However, several lines of evidence suggest that IL-15 is involved in the immunological control of infections with a variety of agents such as Candida albicans (54), Cryptococcus neoformans (41), Aspergillus fumigatus (56), Escherichia coli 
(50), Listeria monocytogenes (23), Mycobacterium leprae (28), Salmonella choleraesuis (45), hepatitis C virus (29) and herpes virus (3). IL-15 also augments Tcell-mediated immunity against Toxoplasma gondii (30) and human immunodeficiency virus (HIV) (20). Exposure of human peripheral blood mononuclear cells to fungi and bacteria such as C. albicans, E. coli and Staphylococcus aureus resulted in rapid up-regulation of NK cell activity via IL-15 induction (52). Thus, IL-15 seems to play a role in the defense against infections by inducing development and activation of effector cells of innate and adaptive immune response involving NK cells, $\gamma \delta$ T cells, T and B cells (57).

\section{Fungal infections}

Studies on the contribution of IL-15 to control fungus infections have been scarce and they preferentially concentrate on its effects on fungicidal activity of monocytes and polymorphonuclear leukocytes (PMN). Vasquez et al. (54) reported the ability of IL-15 to enhance superoxide production and antifungal activity of human monocytes against $C$. albicans. Similar results were obtained when monocytes were treated with IL-2, but to a lesser extent. Association of IL-15 and IL-2 showed no additive or synergistic effects. Additionally, human monocytes showed enhanced killing activity against $C$. albicans after $18 \mathrm{~h}$ of incubation with $\mathrm{IL}-15$ or IL-2, but this treatment did not enhance the ability of these cells to phagocyte the organism. IL-15 has also been pointed as capable of up-regulating antifungal activities in PMN. IL-15 increased phagocytosis of heat-killed $C$. albicans by PMN in a dose-dependent manner and also increased C. albicans-growth-inhibitory activity of PMN (43). Gene expression of innate host defense molecules in normal human monocytes infected with $C$. albicans using the microarray technology was recently evaluated by Kim et al. (31). Freshly isolated peripheral blood monocytes from healthy donors were incubated with $C$. albicans for $18 \mathrm{~h}$ in parallel with time-matched uninfected control cells. Expression of genes encoding pro-inflammatory cytokines, including TNF- $\alpha$, IL-1, IL-6 and leukemia inhibitory factor (LIF), was markedly enhanced during the first $6 \mathrm{~h}$ and coincided with increased phagocytosis.

According to Mody et al. (41), C. neoformans is a potent stimulus for biologically active IL-15 release from monocytes. IL-15 and IL-2 significantly contributed to lymphocyte proliferation and lymphocyte-mediated anticryptococcal activity to both, encapsulate and acapsular C. neoformans. Interestingly, IL-15 restored lymphocyte 
proliferation and anticryptococcal activity that had been abrogated by blocking IL-2. The mechanism of this anticryptococcal activity was more recently reported by Ma et al. (36). These authors observed that the antifungal activity triggered by IL-15 over T CD8 cells correlated with the up-regulation of granulysin, located in the acidic granules.

Previous treatment of human PMN cells with $\mathrm{IL}-15$ for $2 \mathrm{~h}$, in the presence of $A$. fumigatus, increased the production of superoxide anion. After $22 \mathrm{~h}$ of incubation with IL-15, these cells secreted more IL-8 and showed a significant enhancement in their ability to mediate damage to the fungus hyphae, suggesting the contribution of this cytokine during aspergillosis immune control (56).

Addition of IL-15 to human monocyte cultures enhanced fungicidal activity of these cells against Paracoccidioides brasiliensis that is the etiological agent of a severe mycosis called paracoccidioidomycosis. The highest effect was observed after monocyte treatment with $50 \mathrm{ng} / \mathrm{ml}$ of IL-15. Addition of anti-IL-15 monoclonal antibody to the fungal-monocyte co-cultures abrogated this effect, suggesting the contribution of this cytokine to the fungicidal activity of human monocytes against $P$. brasiliensis (5). Human neutrophils cultured with IL-15 also showed increased fungicidal activity against $P$. brasiliensis associated with higher release of hydrogen peroxide from these cells (51). Such studies strongly suggest an important modulatory effect of IL15 on the activation of human monocytes and neutrophils for effective killing of $P$. brasiliensis.

\section{Bacterial infections}

IL-15 seems to play an important role in host defense against infections caused by intracellular bacteria. The main mechanism responsible for this protection seems to involve synergy between IL-12 and IL-15 that activates NK cells, $\gamma \delta$ T cells or NKT cells to produce IFN- $\gamma$, which subsequently induces Th1 response mediated by $\alpha \beta T$ cells. Intracellular in vitro infection with $M$. leprae induced IL-15 secretion from peripheral blood monocytes of lepromatous patients. Interestingly, IL-15 mRNA and protein were more strongly expressed in resistant tuberculoid patients than in those with susceptible lepromatous form (28). IL-15 is also involved in the early activation of intestinal intraepithelial lymphocytes (i-IEL) after oral infection with $L$. monocytogenes (57). The production of this cytokine by enterocytes may be involved in the protection against intestinal infection through stimulation of a significant 
fraction of $\mathrm{i}-\mathrm{IEL}$ to produce and release IFN- $\gamma$. (23) that would then activate macrophages at an early phase of oral infection with L. monocytogenes.

IL-15 derived from macrophages infected with $S$. choleraesuis may contribute to the early activation of $\gamma \delta$ T cells during infection, since $\gamma \delta$ T cells (which express $\beta$ and $\gamma$ chains of IL-2R) proliferated in the presence of rIL-15 and produced appreciable levels of IFN- $\gamma$ and IL-4 (45). According to Mizuno (40), macrophages and dendritic cells, which increase in number soon after Salmonella infection, produce a variety of cytokines, including IL-12, IL-15 and IL-18 that play important roles in the protection against Salmonella infection, proliferation of NK cell, T cell and $\gamma \delta$ T cell and IFN- $\gamma$ production.

Macrophages from $\mathrm{C} 3 \mathrm{H} / \mathrm{HeN}$ mice (lipopolysaccharide-responsive) infected with $E$. coli expressed higher levels of interleukin-15 mRNA than those from the infected $\mathrm{C} 3 \mathrm{H} / \mathrm{HeJ}$ mice (LPS-hyporesponsive). Administration of anti-IL-15 monoclonal antibody inhibited the appearance of $\gamma \delta \mathrm{T}$ cells in $\mathrm{C} 3 \mathrm{H} / \mathrm{HeN}$ mice after $E$. coli infection, which diminished the host defense against the infection. These results suggest that LPS-stimulated $\gamma \delta T$ cells play an important role in the host defense against $E$. coli infection and that IL-15 may be partly involved in the protection via an increase in the $\gamma \delta \mathrm{T}$ cells (50). In addition, more recently, it has been suggested that IL-15 contributes to $E$. coli control by Th2 activation and subsequent antibody production (57).

\section{Other infections}

Possible contributions of IL-15 to enhance immune functions that are destroyed during HIV infection have been partially elucidated. Treatment of peripheral blood mononuclear cells (PBMC) from HIV-infected patients with IL-15 restored the deficient production of $\mathrm{IL}-12$ by these cells and resulted in increased NK cell cytotoxicity to levels similar to those found in healthy donors (16). Also, in vitro treatment of PBMC from HIV-infected adults with IL-15 prevented apoptosis of lymphocytes by suppressing the down-modulation of Bcl-2 I (15). In a recent study, IL-15 increased the immune response of HIV-infected patients by augmenting and/or modulating IFN- $\gamma$ production and beta-chemokine release. Such information about the restorative properties of $\mathrm{IL}-15$ is relevant because they could provide new directions in the immune-based therapies in HIV infection (20). IL-15 participation in 
the host defense in other viral infections, such as herpes virus in humans is, until now, been attributed only to NK cell cytotoxicity enhancement $(1,3)$.

D'Ettorre et al. (18) evaluated clinical and immunological parameters and outcome of patients with visceral leishmaniasis, including HIV positive patients. They observed that visceral leishmaniasis in HIV-infected patients occurred in subjects with severe immunodeficiency which presented high rates of leishmaniasis relapses. Low levels of IL-15 in patients and restored production in cured persons suggest that this cytokine could play an important role in immune response during Leishmania/HIV coinfection. The potential contribution of IL-15 to Leishmania killing was examined in PMA-activated macrophages infected with Leishmania infantum. The killing of $L$. infantum in macrophages primed with IL-15 was followed by an increase in the IL-12 synthesis. These observations indicate that IL-15 could have a role as an activator of leishmanicidal activity, directly or indirectly by inducing IL-12 production (17).

Addition of IL-15 to $\gamma \delta$ T cells from malaria-naïve patients, cultured with Plasmodium falciparum in vitro, resulted in inhibition of parasite replication (19).

It is well described that Th1 cytokines are fundamental to control infections caused by $T$. gondii in mice. Administration of recombinant IL-15 with soluble Toxoplasma lysate provides complete protection against a lethal parasite challenge (30). Additionally, in vitro experiments demonstrated that IL-15 could stimulate resting NK cells to enhance production of IFN- $\gamma$ by mouse splenocytes stimulated with $T$. gondii. These results suggest that IL-15 may be involved in resistance to infections throughout IFN- $\gamma$ production by NK cells (25).

\section{CONCLUSIONS AND PERSPECTIVES}

IL-15 is a pleiotropic and multifunctional cytokine that has a diverse array of distinct biological effects in the body. IL-15 is especially produced by monocytes/macrophages against infectious agents, being an important proinflammatory cytokine that induce phagocytic cell activation against pathogens. As stressed in literature, IL-15 plays a pivotal role in the innate and acquired immune responses during infections by a variety of microorganisms. Therefore, IL-15 contribution to the homeostasis of the immune system and its immunostimulatory activities on cells involved in microbial clearance suggest its potential use for 
treatment of immunodeficiency and as co-adjuvant therapy in human infectious diseases.

\section{REFERENCES}

1 AHMAD A., SHARIF-ASKARI E., FAWAZ L., MENEZES J. Innate immune response of the human host to exposure with herpes simplex virus type 1: in vitro control of the virus infection by enhanced natural killer activity via interleukin-15 induction. J. Virol., 2000, 74, 7196-203.

2 ARMITAGE RJ., MACDUFF BM., EISENMAN J., PAXTON R., GRABSTEIN KH. IL-15 has stimulatory activity for the induction of $B$ cell proliferation and differentiation. J. Immunol., 1995, 154, 483-90.

3 ATEDZOE BN., AHMAD A., MENEZES J. Enhancement of natural killer cell cytotoxicity by the human herpesvirus-7 via IL-15 induction. J. Immunol., 1997, 159, 4966-72.

4 BADOLATO R., PONZI AN., MILLESIMO M., NOTARANGELO LD., MUSSO T. Interleukin (IL-15) induces IL-8 and monocyte chemotactic protein-1 production in human monocytes. Blood, 1997, 90, 2804-9.

5 BANNWART CF., MARTINS RAR., NAKAIRA ET., NASCIMENTO MPP., SOARES AMVC., PERAÇOLI MTS. Interleukin-15 enhances fungicidal activity of human monocytes infected in vitro with Paracoccidioides brasiliensis. J. Venom. Anim. Toxins incl. Trop. Dis. 2006, 12, 327.

6 BECKNELL B., CALIGIURI MA. Interleukin-2, interleukin-15 and their roles in human natural killer cells. Adv. Immunol., 2005, 86, 209-39.

7 BOUCHARD A., RATTHE C., GIRARD D. Interleukin-15 delays human neutrophils apoptosis by intracellular events and not via extracellular factors: role of Mcl-1 and decreased activity of caspase-3 and caspase-8. J. Leukoc. Biol., 2004, 75, 893-900. 8 BUDAGIAN V., BULANOVA E., ORINSKA Z., LUDWIG A., ROSE-JOHN S., SAFTIG P., BORDEN EC., BULFONE-PAUS S. Natural soluble interleukin-15R alpha is generated by cleavage that involves the tumor necrosis factor-alpha converting enzyme (TACE/ADAM17). J. Biol. Chem., 2004, 279, 40368-75.

9 BUDAGIAN V., BULANOVA E., PAUS R., BULFONE-PAUS S. IL-15/IL-15 receptor biology: a guided tour through an expanding universe. Cytokine Growth Factor Rev., 2006, 17, 259-80. 
10 BULFONE-PAUS S., UNGUREANU D., POHL T., LINDNER G., PAUS R., RUCKERT R., KRAUSE H, RUNZENDORF U. Interleukin-15 protects from lethal apoptosis in vivo. Nat. Med., 1997, 3, 1124-8.

11 CARSON WE., CALIGIURI MA. Interleukin-15 is a potential regulator of the innate immune response. Brazilian J. Med. Biol. Res., 1998, 31, 1-9.

12 CARSON WE., GIRI JG., LINDERMANN MJ., LINETT ML., AHDIEH M., PAXTON R., ANDERSON D., EISENMANN J., GRABSTEIN K., CALIGIURI MA. Interleukin (IL-15) is a novel cytokine that activates human natural killer cells via components of the IL-2 receptor. J. Exp. Med., 1994, 180, 1395-403.

13 CARSON WE., ROSS ME., BAIOCCHI RA., MARIEN MJ., BOIANI M., GRABSTEIN K., CALIGIURI MA. Endogenous production of interleukin-15 by activated human monocytes is critical for optimal production of interferon-gamma by natural killer cells in vitro. J. Clin. Invest., 1995, 96, 2578-82.

14 CASSATELLA MA., MCDONALD PP. Interleukin-15 and its impact on neutrophil function. Curr. Opin. Hematol., 2000, 7, 174-7.

15 CHANG KH., KIM JM., KIM HY., SONG YG., CHOI YH., PARK YS., CHO JH., HONG SK. Spontaneous programmed cell death of peripheral blood mononuclear cells from HIV-infected persons is decreased with interleukin-15. Yonsei Med. J., 2000, 41, 112-8.

16 CHEHIMI J., MARSHALL JD., SALVUCCI O., FRANK I., CHEHIMI S., KAWECKI S., BACHELLER D., RIFAT S., CHOUAIB S. IL-15 enhances immune functions during HIV infection. J. Immunol., 1997, 158, 5978-87.

17 D'AGOStinO P., MILANO S., ARCOlEO F., DI BELlA G., LA ROSA M., FERLAZZO V., CARUSO R., CHIFARI N., VITALE G., MANSUETO S., CILBARI E. Interleukin-15, as interferon-gamma, induces the killing of Leishmania infantum in phorbol-myristate-acetate-activated macrophages increasing interleukin-12. Scand. J. Immunol., 2004, 60, 609-14.

18 D'ETORRE G., CECCARELLI G., CARNEVALINI M., FORCINA G., ZAFFIRI L., MASSETTI AP., MASTROIANNI CM., VULLO V. Central role of interleukin-15 in human immunodeficiency virus (HIV)-infected patients with visceral leishmaniasis. Acta Trop., 2006, 99, 83-7.

19 ELLOSO MM., WALLACE M., MANNING DD., WEIDANZ WP. The effects of interleukin-15 on human gamma delta $T$ cell responses to Plasmodium falciparum in vitro. Immunol. Lett., 1998, 64, 125-32. 
20 FORCINA G., D'ETTORRE G., MASTROIANNI CM., CARNEVALINI M., SCORZOLINI L., CECCARELLI G., D'AGOSTINO C., LICHTNER M., MASSETTI AP., VULLO V. Interleukin-15 modulates interferon-gamma and beta-chemokine production in patients with HIV infection: implications for immune-based therapy. Cytokine, 2004, 25, 283-90.

21 GIRI JG., AHDIEH M., EISENMAN J., SHANEBECK K., GRABSTEIN KH., KUMAKI S., NAMEN A., PARK LS., COSMAN D., ANDERSON D. Utilization of the beta and gamma chains of the IL-2 receptor by the novel cytokine IL-15. EMBO J., 1994, 13, 2822-30.

22 GRABSTEIN KH., EISENMAN J., SHANEBECK KD., RAUCH C., SRINIVASAN S., FUNG V., BEERS C., RICHARDSON J., SCHOENBORN MA., AHDIEH M., JOHNSON L., ALDERSON MR., WATSON JD., ANDERSON DM., GIRI JG. Cloning of a $T$ cell growth factor that interacts with the beta chain of the interleukin-2 receptor. Science, 1994, 264, 965-8.

23 HIROSE K., SUZUKI H., NISHIMURA H., MITANI A., WASHIZY J., MATSUGUCHI T., YOSHIKAI Y. Interleukin-15 may be responsible for early activation of intestinal intraepithelial lymphocytes after oral infection with Listeria monocytogenes in rats. Infect. Immun., 1998, 66, 5677-83.

24 HOONTRAKOON R., CHU WH., GARDAI SJ., WENZEL SE., MCDONALD P., FADOK VA., HENSON PM., BRATTON DL. Interleukin-15 inhibits spontaneous apoptosis in human eosinophils via autocrine production of granulocyte macrophagecolony stimulation factor and nuclear factor-kB activation. Am. J. Respir. Cell. Mol. Biol., 2002, 26, 404-12.

25 HUNTER CA., ELLIS-NEYER L., GABRIEL KE., KENNEDY MK., GRABSTEIN KH., LINSLEY PS., REMINGTON JS. The role of the CD28/B7 interaction in the regulation of NK cell responses during infection with Toxoplasma gondii. J. Immunol., 1997, 158, 2285-93.

26 JAMES SL., NACY C. Effector functions of activated macrophages against parasites. Curr. Opin. Immunol., 1993, 5, 518-24.

27 JOHNSTON JA., BACON CM., FINBLOOM DS., REES RC., KAPLAN D., SHIBUYA K., ORTALDO JR., GUPTA S., CHEN YO., GIRI JD. Tyrosine phosphorylation and activation of STAT5, STAT3, and Janus kinases by interleukins 2 and 15. Proc. Natl. Acad. Sci. USA, 1995, 92, 8705-9. 
28 JULLIEN D., SIELING PA., UYEMURA K., MAR ND., REA TH., MODLIN RL. IL15 an immunomodulator of $\mathrm{T}$ cell responses in intracellular infection. J. Immunol., 1997, 158, 800-6.

29 KAKUMU S., OKUMURA A., ISHIKAWA T., YANO M., ENOMOTO A., NISHIMURA H., YOSHIOKA K., YOSHIKAI Y. Serum levels of IL-10, IL-15 and soluble tumor necrosis factor-alpha (TNF-alpha) receptors in type $C$ chronic liver disease. Clin. Exp. Immunol., 1997, 109, 458-63.

30 KHAN IA., KASPER LH. IL-15 augments CD8+ T cell-mediated immunity against Toxoplasma gondii infection in mice. J. Immunol., 1996, 157, 2103-8.

31 KIM HS., CHOI EH., KHAN J., ROILIDES E., FRANCESCONI A., KASAI M., SEINT T., SCHAUFELE RL., SAKURAI K., SON CG., GREER BT., CHANOCK S., LYMAN CA., WALSH TJ. Expression of genes encoding innate host defense molecules in normal human monocytes in response to Candida albicans. Infect. Immun., 2005, 73, 3714-24.

32 LEONARD WJ. Role of JAK kinases and STATs in cytokine signal transduction. Int. J. Hematol., 2001, 73, 271-7.

33 LEONARD WJ., SHORES EW., LOVE PE. Role of the common cytokine receptor gamma chain in cytokine signaling and lymphoid development. Immunol. Rev., 1995, 148, 97-114.

34 LODOLCE JP., BURKETT PR., KOKA RM., BOONE DL., MA A. Regulation of lymphoid homeostasis by interleukin-15. Cytokine Grow Factor Rev., 2002, 13, 42939.

35 MA A., KOKA R., BURKETT P. Diverse functions of IL-2, IL-15 and IL-7 in lymphoid homeostasis. Annu. Rev. Immunol., 2006, 24, 657-79.

36 MA LL., SPURRELL JC., WANG JF., NEELY GG., EPELMAN S., KRENSKY AM., MODY $\mathrm{CH}$. CD8 $\mathrm{T}$ cell-mediated killing of Cryptococcus neoformans requires granulysin and is dependent on CD4 T cells and IL-15. J. Immunol., 2002, 169, 5787-95.

37 McDONALD PP., RUSSO MP., FERRINI S., CASSATELA MA. Interleukin-15 induces NF-kappaB activation and IL-8 production in human neutrophils. Blood, 1998, 92, 4828-35. 
38 MAEURER MJ., TRINDER P., HOMMEL G., WALTER W., FREITAG K., ATKINS D., STORKEL S. Interleukin-7 or interleukin-15 enhances survival of Mycobacterium tuberculosis-infected mice. Infect. Immun., 2000, 68, 2962-70.

39 MATTEI F., SCHIAVONI G., BELARDELLI F., TOUGH DF. IL-15 is expressed by dendritic cells in response to type I IFN, double-stranded RNA or lipopolysaccharide and promotes dendritic cell activation. J. Immunol., 2001, 167, 1179-87.

40 MIZUNO Y. Host defense mechanisms against Salmonella infection. Nihon Rinsho Meneki Gakkai Kaishi, 2004, 27, 367-72.

41 MODY $\mathrm{CH}$., SPURREL JC., WODD CJ. Interleukin-15 induces antimicrobial activity after release by Criptococcus neoformans-stimulated monocytes. J. Infect. Dis., 1998, 178, 803-14.

42 MORTIER E., BERNARD J., PLET A., JACQUES Y. Natural proteolytic release of a soluble form of human IL-15 receptor $\alpha$-chain that behaves as a specific, high affinity IL-15 antagonist. J. Immunol., 2004, 173, 1681-8.

43 MUSSO T., CALOSSO L., ZUCCA M., MILLESIMO M., RAVARINO D., GIOVARELLI M., MALAVASI F., PONZI NA., PAUS R., BULFONE-PAUS S. Human monocytes constitutively express membrane-bound, biologically active, and interferon-gamma-upregulated interleukin-15. Blood, 1999, 93, 3531-9.

44 NEELY GG., EPELMAN S., MA LL., COLARUSSO P., HOWLETT CJ., AMANKWAH EK., McINTIRE AC., ROBBINS SM., MODY CH. Monocytes surfacebound IL-15 can function as an activating receptor and participate in reverse signaling. J. Immunol., 2004, 172, 4225-34.

45 NISHIMURA H., HIROMATSU K., KOBAYASHI N., GRABSTEIN KH., PAXTON R., SAGAMURA K., BLUESTONE JA., YOSHIKAI Y. IL-15 in a novel growth for murine gamma delta T cells induced by Salmonella infection. J. Immunol., 1996, 156, $663-9$.

46 OHTEKI T., SUZUE K., MAKI C., OTA T., KOYASU S. Critical role of IL-15- IL$15 \mathrm{R}$ for antigen-presenting cell functions in the innate immune response. Nat. Immunol., 2001, 2, 1138-43.

47 PARK CS., YOON SO., ARMITAGE RJ., CHOI YS. Follicular dendritic cells produce IL-15 that enhances germinal center B cell proliferation in membrane-bound form. J. Immunol., 2004, 173, 6676-83. 
48 RATTHE C., GIRARD D.. Interleukin-15 enhances human neutrophils phagocytosis by a Syk-dependent mechanism: importance of the IL-15R alpha chain. J. Leukoc. Biol., 2004, 76, 162-8.

49 TAGAYA Y., BURTON JD., MIYAMOTO Y., WALDMANN TA. Identification of a novel receptor/signal transduction pathway for IL-15/T in mast cells. EMBO J., 1996, 15, 4928-39.

50 TAKANO M., NISHIMURA H., KIMURA Y., MOKUNO Y., WASHIZU J., ITOHARA S., NIMURA Y., YOSHIKAI Y. Protective roles of gamma delta T cells and interleukin15 in Escherichia coli infection in mice. Infect. Immun., 1998, 66, 3270-10.

51 TAVIAN EG., DIAS-MELICIO LA., BORDON AP., ACORCI MJ., BIONDO GA., PERAÇOLI MT., SOARES AMVC. Effect of IL-15 on fungicidal activity and $\mathrm{H}_{2} \mathrm{O}_{2}$ release by human neutrophils challenged with high virulent strain of Paracoccidioides brasiliensis. J. Venom. Anim. Toxins incl. Trop. Dis., 2006, 12, 340.

52 TRAN P., AHMAD R., XU J., AHMAD A., MENEZES J. Host's innate immune response to fungal and bacterial agents in vitro: up-regulation of interleukin-15 gene expression resulting in enhanced natural killer activity. Immunology, 2003, 109, 26370.

53 VAN BELLE T., GROOTEN J. IL-15 and IL-15R $\alpha$ in CD4+ T cell immunity. Arch. Immunol. Ther. Exp. (Warsz), 2005, 53, 115-26.

54 VAZQUEZ N., WALSH TJ., FRIEDMAN D., CHANOCK SJ., LYMAN CA. Interleukin-15 augments superoxide production and microbicidal activity of human monocytes against Candida albicans. Infect. Immun., 1998, 66, 145-50.

55 WALDMANN TA., TAGAYA Y. The multifaceted regulation of interleukin-15 expression and the role of this cytokine in NK cell differentiation and host response to intracellular pathogens. Annu. Rev. Immunol., 1999, 17, 19-49.

56 WINN RM., GIL-LAMAIGNERE C., ROILIDES E., SIMITSOPOULOU M., LYMAN CA., MALOUKOU A., WALSH TJ. Selective effects of interleukin (IL)-15 on antifungal activity and IL-8 release by polymorphonuclear leukocytes in response to hyphae of Aspergillus species. J. Infect. Dis., 2003, 188, 585-90.

57 YOSHIKAI Y., NISHIMURA H. The role of interleukin-15 in mounting an immune response against microbial infection. Microbes Infect., 2000, 2, 381-9. 